\title{
Coatings role in the baby kiwi shelf life
}

\author{
L. Brondino, C. Peano and N.R. Giuggiolia \\ Department of Agricultural, Forest and Food Sciences, University of Turin, Turin, Italy.
}

\begin{abstract}
Baby kiwi, also called hardy kiwi (Actinida arguta) is native to East Asia and currently commercialized in USA, Canada, Chile, New Zealand and Europe; however, it is still relatively unknown to consumers. In recent years, baby kiwi has gained popularity due to its nutraceutical superiority over the well-accepted green kiwi and its ease of consumption - when ripe, hardy kiwi is suitable for direct consumption without peeling. Hardy kiwi is typically harvested at commercial maturity, so weight losses and pulp hardness are the most difficult parameters in postharvest management of the supply chain and the availability of fruits in the fresh market. This work was focused on the hardy kiwi 'Hortgem Rua ${ }^{\circledR}$ ', marketed under the $\mathrm{Nergi}^{\circledR}$ brand and cultivated in the Piedmont region of northern Italy. The aim was to evaluate the application of two different coatings, $\mathrm{C} 1$ (commercial formulation in the absence of amines, made from natural shellac dissolved in ethyl alcohol) and C2 (commercial formulation based on sucrose ester), in the maintenance of shelf life up to 21 days at 2 and $24^{\circ} \mathrm{C}$. Qualitative analyses (weight loss, skin colour, texture profile analysis, soluble solid content and titratable acidity) were performed at harvest time ( 0 days) and every 3 days thereafter. The results indicate that the $\mathrm{C} 1$ coating was better for reducing moisture loss, maintaining pulp hardness and containing the evolution of soluble solid content throughout the shelf life at $24 \pm 1^{\circ} \mathrm{C}$ of 'Hortgem Rua ${ }^{\circledR}$ '. However, there was no improvement in shelf life at $2 \pm 1^{\circ} \mathrm{C}$.
\end{abstract}

Keywords: Actinidia arguta, coating, quality, texture, shelf life

\section{INTRODUCTION}

Baby kiwi, also known as minikiwi, hardy kiwi or kiwi berry, belongs to Actinidia arguta. In recent years, it has gained popularity among consumers due to its nutraceutical superiority (it is considered as a superfood or super snack) over the well-accepted green kiwi and the ease of consumption - when ripe, hardy kiwi is suitable for direct consumption without peeling. Moreover, it is resistant to Pseudomonas syringae pv. actinidiae, which has become a major problem among yellow-fleshed kiwifruit (Actinidia chinensis var. chinensis) producers. In fact, this crop can be considered an opportunity for the conversion of farms affected by significant yield losses caused by the agent of bacterial canker. The market is relatively new, so official data on world production are difficult to report due to a dynamic scenario that involves the producers and all the players interested in the supply chain (Latocha et al., 2018). Actinidia arguta fruits are known for their soft and easily consumed berries, but they are also characterized by a limited shelf life. In fact, baby kiwi is typically harvested at commercial maturity, so time is allowed for storage until the fruit reaches its physiological maturity. Once at that stage, its shelf life is very short (Fisk et al., 2006). Postharvest research is essential to reduce waste, and warehouse management can optimize the future success of fruit marketability (Giuggioli et al., 2019). Weight losses and the degree of pulp hardness are the main problems that need to be managed in the postharvest supply chain (Fisk et al., 2008). The expansion of fresh berries to market at both the national and the international levels must consider with great attention these two qualitative parameters. Studies on a modified, controlled atmosphere and 1 MCP application to control ethylene production are mainly reported to improve fruit shelf life (Szpadzik et al., 2021; Latocha et al., 2014) but those on baby kiwi coating applications are limited (Fisk et al., 2008; Yang et al., 2010; Kaya et al., 2016).

aE-mail: nicole.giuggioli@unito.it 
Coatings are largely studied on tropical fruits (Md Nor and Ding, 2020) and fresh cut kiwifruits, and the main objective is to evaluate the antioxidant properties to improve fruit shelf life and to limit browning decay (Manzoor et al., 2021). Different coating types are available (Liu et al., 2021; Pobiega et al., 2021), made of different combined materials such as polysaccharides (cellulose, hemicellulose, starch, chitosan and gums), proteins and lipids, and they are considered a promising solution to procuring safe food without any chemical postharvest treatments. The external coating acts as a modified atmosphere, obtaining better control of moisture loss and gas diffusion, and is able to slow down the ripening process. Actually, coatings are mainly studied and applied on apples; the performances of coatings largely depend on a mix of factors such as the ingredients of the coating, the adherence on the fruit surface, the permeability to gas and water and the thickness of the film (Maringgal et al., 2020). Therefore, the main aim of this study was to evaluate the effect of two commercial coatings on qualitative traits, particularly on weight losses and the degree of pulp hardness in baby kiwi stored at refrigerated temperature $\left(2 \pm 1^{\circ} \mathrm{C}\right)$ and at room temperature $\left(24 \pm 1^{\circ} \mathrm{C}\right)$ for up to 21 days.

\section{MATERIALS AND METHODS}

\section{Fruit samples and storage conditions}

Fruits of Actinidia arguta (Siebold \& Zucc.) Planch. ex Miq cultivar 'Hortgem Rua ${ }^{\circledR}$ branded with the Nergi ${ }^{\circledR}$ name were considered. Fruits are characterized by a reddish pulp when physiologically mature, an oblong shape and a sweet, aromatic taste (McNeilage et al., 2004). Fruit were hand harvested at the ripening stage (middle of August) from a commercial orchard of the Ortofruititalia Soc .Coop. (Piedmont, Italy). The ripening stage was defined following the characteristics of the fruits sweetness ( ${ }^{\circ}$ Brix level) averages approximately $12.4 \%$ as reported by McNeilage et al. (2004). The baby kiwi were graded for uniformity of colour (fruit skin colour at harvest is within the range near Green 140A to near Green 143B according to the Royal Horticultural Society Colour Chart) and size (median weights of 13.1-15.0 g), and damaged fruits were removed. The fruits were individually packed in PLA trays $(150 \mathrm{~g})$ (consumer unit) and transported to the laboratory of the Department of Agricultural, Forest and Food Sciences (DISAFA), University of Turin. The experimental set-up started approximately $3 \mathrm{~h}$ after harvest. Coating materials used in this study were two commercial formulations. The first one was Xedasol L in the absence of amines, made from natural shellac dissolved in ethyl alcohol (C1), and the second was Semperfresh ${ }^{\mathrm{TM}}$ formulation based on shortchain sucrose esters of fatty acids, sodium carboxymethyl, mono- and diglycerides of fatty acids (C2). Coated samples were compared with untreated fruit (control). Samples of baby kiwi were dipped in $\mathrm{C} 1$ and $\mathrm{C} 2$ solution for $30 \mathrm{~s}$ and, after drying in air, were packed. Baskets were coded before the treatments. The packages (three replicates each treatment), each containing $0.150 \mathrm{~kg}$ of baby kiwi, were stored in a controlled cool storage room $\left(2 \pm 1^{\circ} \mathrm{C}\right)$ and at room temperature $\left(24 \pm 1^{\circ} \mathrm{C}\right)$ up to 21 days. The relative humidity was maintained in the range of $90-95 \%$ and no movement of the cooling air was present due the static cell used. All the quality controls were monitored at the harvest ( 0 days) and every 3 days up to 21 of storage, and all the results were expressed as an average of three randomly selected trays.

\section{Weight loss and quality evaluations}

Weight loss (\%) was determined using an electronic balance (model SE622, VWR Science Education, Radnor, Pennsylvania, USA), with a $10^{-2} \mathrm{~g}$ accuracy. Weight was monitored during the entire storage period and was calculated as the difference between initial (Wo) and final (Wt) basket weights.

$$
\text { Weight loss }(\%)=\frac{W o-W t}{W o} \times 100
$$

The texture profile analysis (TPA) assessment was conducted with a texturometer (TA.XTplus; Stable Micro Systems, Godalming, UK) with a 75-mm aluminium compression 
plate (P/75). For the TPA test, a 25\% strain was applied, with a pre-test speed of $1 \mathrm{~mm} \mathrm{~s}^{-1}$, a test speed of $5 \mathrm{~mm} \mathrm{~s}^{-1}$ and a 5 -g trigger force (Giuggioli et al., 2017). The following TPA parameters from the resulting force-time curve were registered: hardness, springiness, cohesiveness, adhesiveness, gumminess, chewiness and resilience. Three replicates (each one comprising 15 fruits) were included for each of the measurements. All measurements were performed on the total of 15 fruits. Total soluble solids (TSS) were determined with a digital Atago PR-101 (Atago, Japan) at $20^{\circ} \mathrm{C}$, and the results were expressed as ${ }^{\circ} \mathrm{Brix}$. The titratable acidity (TA) of the baby kiwi juice obtained from 15 fruits was determined in triplicate by titration with $0.1 \mathrm{~N} \mathrm{NaOH}$ to $\mathrm{pH} 8.1$ using $10 \mathrm{~mL}$ of diluted juice in distilled $\mathrm{H}_{2} \mathrm{O}$, and the results were expressed as meq $\mathrm{L}^{-1}$. The ratio of TSS to TA (Ratio TSS/TA) was calculated. Colourimetric analyses were performed with a Minolta chroma-meter colourimeter (CR400; Minolta, Ramsey, NJ, USA) using the CIELAB scale defined by the Commission International de L'Eclairage, in which L* (lightness/darkness), a* (redness/greenness) and b* (yellowness/ blueness) are mutually perpendicular axes.

\section{Statistical analysis}

All statistics were performed using SPSS for Windows version 27.0. The data obtained were treated with one-way analysis of variance (ANOVA), and the means were separated using the Tukey test $(\mathrm{P} \leq 0.05)$.

\section{RESULTS AND DISCUSSION}

\section{Weight losses}

The weight losses of fruits are linked to water loss, and the management of this parameter is fundamental to the postharvest marketability of products. Baby kiwi, due their small size, show a high surface area/volume ratio if compared to traditional kiwi (A. chinensis var. deliciosa), and this causes higher water losses. The maximum acceptable weight loss in saleable baby kiwi is reported to be $6 \%$ (Giuggioli et al., 2019). Figure 1 shows the weight loss of baby kiwi fruits during 21 days at $2 \pm 1^{\circ} \mathrm{C}$ and $24 \pm 1^{\circ} \mathrm{C}$. Ambient temperature $\left(24 \pm 1^{\circ} \mathrm{C}\right)$ is a non-optimal condition for fruit storage due to the increase in water vapour pressure deficit. Samples, in fact, can be maintained for only up to 9 days, but already after 3 days, fruits become non-saleable considering the previous value of percentage limit. The fruit was maintained at a cold temperature $\left(2 \pm 1^{\circ} \mathrm{C}\right)$ for the duration of the experiment, and statistically significantly differences were observed among treated samples at each time point. No significantly statistically differences were observed among C1 coating treatments and control samples, while the $\mathrm{C} 2$ treatment showed the worst results, losing $6.7 \%$ at the end of 21 days.

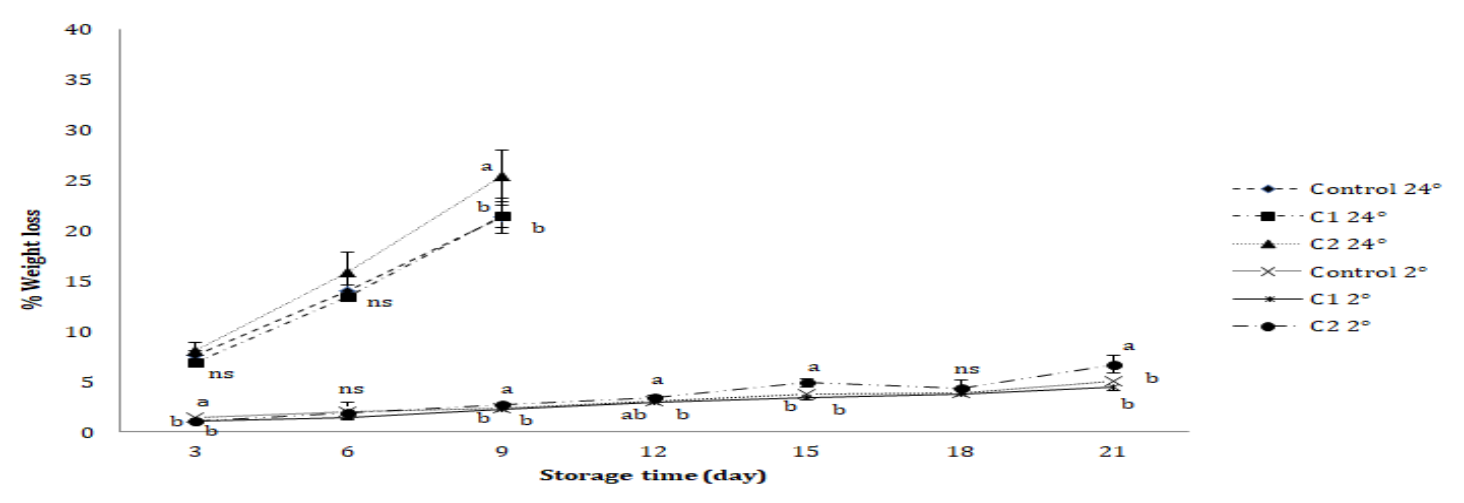

Figure 1. Changes in weight loss of 'Hortgem Rua ${ }^{\circledR}$ ' fruits during 21 days at $2 \pm 1^{\circ} \mathrm{C}$ and $24 \pm 1^{\circ} \mathrm{C}$. For each storage time, values followed by the same letter do not differ significantly according to Tukey's HSD test $(\mathrm{P} \leq 0.05)$. Vertical bars represent standard deviation. 


\section{Quality evaluations}

An important characteristic of baby kiwi is its firmness. This is dependent on the cell wall and its evolution during storage. Ripening fruits soften in texture, a process related to reduction of intercellular adhesion and changes in cell wall polysaccharide composition (Sutherland et al., 2017).

The initial hardness value was $46.07(\mathrm{~N})$, but a decline was observed during the storage time due to metabolic changes and water losses (Figure 2). According to Fisk et al. (2008), baby kiwi maintained at the coldest temperature are harder than those maintained at the highest temperature storage conditions. After 3 days of storage a dramatically decrease was observed for fruit stored at $24 \pm 1^{\circ} \mathrm{C}$ while an unexpected values were observed for fruit stored at $2 \pm 1^{\circ} \mathrm{C}$. In fact these samples showed pulp firmness values higher than those observed at the start time. Probably this was due to the fact that fruits didn't have reached the room temperature before the analysis. Between coatings, the use of $\mathrm{C} 1$ applied on baby kiwi showed a significant effect on keeping hardness values at $24 \pm 1^{\circ} \mathrm{C}$. The coating $\mathrm{C} 2$ was the worst at maintaining pulp consistency and in relation to the greater weight loss observed.

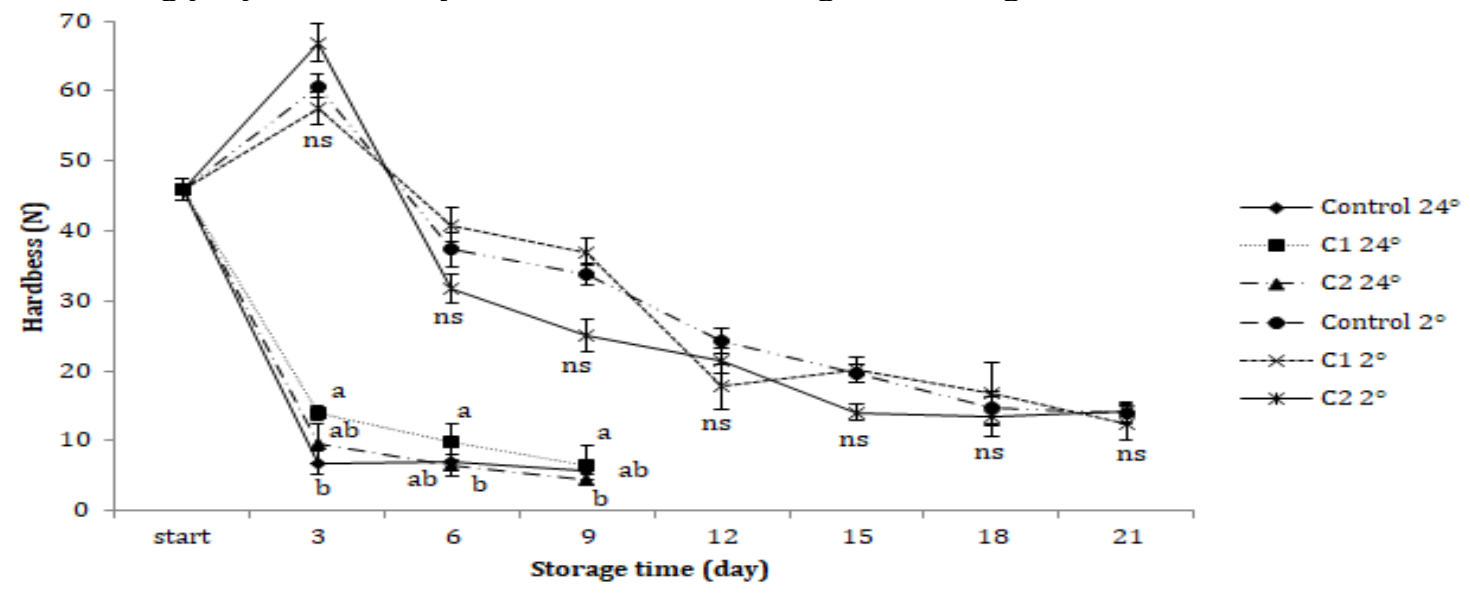

Figure 2. Hardness values (N) of 'Hortge Rua ${ }^{\circledR}$ ' fruits during 21 days at $2 \pm 1^{\circ} \mathrm{C}$ and $24 \pm 1^{\circ} \mathrm{C}$. For each storage time, values followed by the same letter do not differ significantly according to Tukey's HSD test $(\mathrm{P} \leq 0.05)$. Vertical bars represent standard deviation.

One of the most important quality characteristics of baby kiwi is its sweetness after storage. This parameter is directly related to the sugar and starch contents in preharvest development. A valuable lesson from green kiwi is that, although sucrose and planteose are the major sugars during development, adequate storage of starch is essential to produce a desirable flavour. Starch degradation mainly occurs after the fruit is ripe, and by the time it is eaten, almost all starch is converted into soluble sugars. This process is complex and depends on the osmotic pressure, mainly driven by the organic acids present (Nardozza et al., 2013). Qualitative analyses of samples during storage at both temperatures $2 \pm 1^{\circ} \mathrm{C}$ and $24 \pm 1^{\circ} \mathrm{C}$ are reported in Tables 1 and 2, respectively. The TSS of baby kiwi at harvest time (start) is $11.1^{\circ} \mathrm{Brix}$; the results of this study show that TSS was as high as $17.8^{\circ} \mathrm{Brix}$ in fruit stored at room temperature but only $14.7^{\circ}$ Brix in refrigerated fruit at the endo of storage time. Generally, it can be assumed that the C1 coating best limits TSS evolution and weight losses, when compared with $\mathrm{C} 2$ and control conditions. In fact, $\mathrm{C} 2$ seems to increase fruit respiration, thus affecting starch degradation in TSS, so the concentration increases over time with this coating. Statistically significant differences were also observed concerning titratable acidity. Titratable acidity is a good measure of the total organic acid content of fruits and, in relation to TSS (TSS/TA), is an indicator of the organoleptic sweetness of different fruits. At $2 \pm 1^{\circ} \mathrm{C}$ after 9 days of storage, the lowest TA content was observed in C1-coated fruits. The consumer preference of fruits is based on extrinsic quality factors, and the visual aspect, mainly affected by the peel colour, is one of the determinants of product acceptance. In contrast to Actinidia deliciosa fruits, in Actinidia arguta the flesh colour also changes during ripening; therefore, 
colour alteration may be an interesting parameter for evaluation. Colour is one of the most important quality attributes influencing consumer food choices, perceptions and purchase behaviour (Pathare et al., 2013). Even if all the CIELAB colour space data were acquired, changes in the external colour of stored baby kiwi were monitored by reporting the lightness $\left(\mathrm{L}^{*}\right)$. This was according with the marketing staff of the Ortofruititalia warehouse that evaluated, as the luminosity is the most important valuable parameter that affect the consumers evaluation of baby kiwi. The lightness colour parameter was not affected by coating treatments at $2 \pm 1^{\circ} \mathrm{C}$, whereas statistically significant differences were observed at $24 \pm 1^{\circ} \mathrm{C}$. Table 1 shows that $\mathrm{C} 2$ samples darkened according to decreasing values of $\mathrm{L}^{*}$, which became significantly different. These data agree with the observations made for $\mathrm{C} 2$ on weight loss and evolution of TSS - greater fruit senescence.

Table 1 . Physicochemical analyses of baby kiwi samples at $24 \pm 1^{\circ} \mathrm{C}$.

\begin{tabular}{|c|c|c|c|c|}
\hline & \multicolumn{4}{|c|}{ Storage time } \\
\hline & Start & 3 days & 6 days & 9 days \\
\hline \multirow{4}{*}{$\begin{array}{l}\text { Control } \\
\text { C1 24 } \\
\text { C2 24 } \\
\end{array}$} & \multicolumn{4}{|c|}{ TSS ( ${ }^{\circ}$ Brix) } \\
\hline & \multirow[t]{3}{*}{$11.17 \pm 0.06$} & $17.07 \pm 0.06 a$ & $19.13 \pm 0.21 a$ & $17.83 \pm 2.40 \mathrm{~ns}$ \\
\hline & & $15.10 \pm 0.20 b$ & $14.40 \pm 0.10 c$ & $17.77 \pm 2.47 \mathrm{~ns}$ \\
\hline & & $15.47 \pm 0.23 b$ & $16.10 \pm 0.10 \mathrm{~b}$ & $17.67 \pm 2.51 \mathrm{~ns}$ \\
\hline \multirow{5}{*}{$\begin{array}{l}\text { Control } \\
\text { C1 24 } \\
\text { C2 } 24^{\circ} \\
\end{array}$} & \multicolumn{4}{|c|}{ Titratable acidity (meq L-1) } \\
\hline & \multirow[t]{3}{*}{$86.50 \pm 4.71$} & $59.07 \pm 5.05 \mathrm{~ns}$ & $64.83 \pm 4.76 \mathrm{~ns}$ & $60.27 \pm 0.78 \mathrm{~ns}$ \\
\hline & & $72.90 \pm 4.71 \mathrm{~ns}$ & $68.50 \pm 2.23 \mathrm{~ns}$ & $60.27 \pm 4.65 n s$ \\
\hline & & $73.67 \pm 2.73 \mathrm{~ns}$ & $72.30 \pm 1.04 \mathrm{~ns}$ & $72.47 \pm 2.21 \mathrm{~ns}$ \\
\hline & \multirow{4}{*}{$0.13 \pm 0.01$} & \multicolumn{2}{|c|}{ TSS $\times$ titratable acidity } & \multirow{4}{*}{$\begin{array}{l}0.30 \pm 0.02 \mathrm{~ns} \\
0.29 \pm 0.07 \mathrm{~ns} \\
0.24 \pm 0.11 \mathrm{~ns}\end{array}$} \\
\hline \multirow{4}{*}{$\begin{array}{l}\text { Control } \\
\text { C1 24 } \\
\text { C2 24 } \\
\end{array}$} & & $0.29 \pm 0.01 a$ & $0.30 \pm 0.02 a$ & \\
\hline & & $0.21 \pm 0.04 b$ & $0.21 \pm 0.03 b$ & \\
\hline & & $0.21 \pm 0.08 b$ & $0.22 \pm 0.00 \mathrm{~b}$ & \\
\hline & \multirow{4}{*}{$58.03 \pm 0.62$} & & lour (L) & \\
\hline \multirow{3}{*}{$\begin{array}{l}\text { Control } \\
\text { C1 } 24^{\circ} \\
\text { C2 24 }\end{array}$} & & $48.36 \pm 1.65 a$ & $48.48 \pm 1.32 \mathrm{a}$ & $47.82 \pm 1.66 \mathrm{a}$ \\
\hline & & $48.52 \pm 2.70 \mathrm{a}$ & $47.32 \pm 2.03 a$ & $44.40 \pm 3.65 b$ \\
\hline & & $44.10 \pm 2.90 \mathrm{~b}$ & $44.94 \pm 3.09 b$ & $42.07 \pm 3.10 \mathrm{~b}$ \\
\hline
\end{tabular}

Data are the means \pm standard deviation. For each storage time different qualitative values followed by the same letter do not differ significantly according to Tukey's HSD test $(P \leq 0.05)$.

In addition to the hardness previously discussed, some TPA parameters (gumminess, resilience and adhesiveness) are reported in Tables 3 and 4. Due to the highest values of fruit hydration, as expected, the $\mathrm{C} 1$ sample at the end of the storage period ( 9 days at $24 \pm 1^{\circ} \mathrm{C}$ ) showed statistically significant differences in terms of gumminess and resilience parameters, maintaining the highest values. No differences were observed at $+2 \pm 1^{\circ} \mathrm{C}$. 
Table 2. Physicochemical analyses of baby kiwi samples at $2 \pm 1^{\circ} \mathrm{C}$.

\begin{tabular}{|c|c|c|c|c|c|c|c|c|}
\hline & \multicolumn{8}{|c|}{ Storage time } \\
\hline & Start & 3 days & 6 days & 9 days & 12 days & 15 days & 18 days & 21 days \\
\hline $\begin{array}{l}\text { Control } \\
\text { C1 } 2^{\circ} \\
\mathrm{C} 22^{\circ}\end{array}$ & $11.17 \pm 0.06$ & $\begin{array}{l}11.10 \pm 0.17 \mathrm{~ns} \\
10.97 \pm 0.15 \mathrm{~ns} \\
10.97 \pm 0.15 \mathrm{~ns}\end{array}$ & $\begin{array}{l}12.27 \pm 0.06 a \\
10.67 \pm 0.12 b \\
12.23 \pm 0.06 a\end{array}$ & $\begin{array}{l}12.57 \pm 0.15 a \\
10.97 \pm 0.15 b \\
12.70 \pm 0.10 a\end{array}$ & $\begin{array}{l}\text { TSS }\left({ }^{\circ} \text { Brix }\right) \\
13.10 \pm 1.10 \mathrm{~ns} \\
12.87 \pm 0.78 \mathrm{~ns} \\
13.00 \pm 0.87 \mathrm{~ns} \\
\end{array}$ & $\begin{array}{l}14.23 \pm 0.12 a \\
12.43 \pm 0.15 c \\
13.73 \pm 0.06 b\end{array}$ & $\begin{array}{l}14.57 \pm 0.06 a \\
13.60 \pm 0.10 \mathrm{c} \\
13.97 \pm 0.12 b\end{array}$ & $\begin{array}{l}14.73 \pm 0.06 a \\
12.57 \pm 0.06 c \\
14.13 \pm 0.12 b\end{array}$ \\
\hline $\begin{array}{l}\text { Control } \\
\text { C1 } 2^{\circ} \\
\text { C2 } 2^{\circ}\end{array}$ & $86.50 \pm 4.71$ & $\begin{array}{l}79.13 \pm 3.94 \mathrm{~ns} \\
74.67 \pm 3.09 \mathrm{~ns} \\
75.13 \pm 3.85 \mathrm{~ns}\end{array}$ & $\begin{array}{l}75.83 \pm 3.27 \mathrm{~ns} \\
59.60 \pm 2.07 \mathrm{~ns} \\
83.83 \pm 1.00 \mathrm{~ns}\end{array}$ & $\begin{array}{l}\text { Titrat } \\
67.23 \pm 3.99 \mathrm{~b} \\
67.77 \pm 2.30 \mathrm{~b} \\
79.53 \pm 2.19 \mathrm{a} \\
\end{array}$ & $\begin{array}{c}\text { ocidity (meq L-1) } \\
77.97 \pm 4.48 \mathrm{ab} \\
71.97 \pm 1.17 \mathrm{~b} \\
82.10 \pm 3.84 \mathrm{a} \\
\end{array}$ & $\begin{array}{l}84.70 \pm 1.25 \mathrm{~ns} \\
70.60 \pm 1.40 \mathrm{~ns} \\
83.20 \pm 5.73 \mathrm{~ns}\end{array}$ & $\begin{array}{l}82.27 \pm 1.24 a \\
73.20 \pm 1.71 b \\
79.80 \pm 0.85 a\end{array}$ & $\begin{array}{l}77.27 \pm 3.30 \mathrm{a} \\
64.83 \pm 2.75 \mathrm{~b} \\
77.17 \pm 1.03 \mathrm{a}\end{array}$ \\
\hline $\begin{array}{l}\text { Control } \\
\text { C1 } 2^{\circ} \\
\text { C2 } 2^{\circ}\end{array}$ & $0.13 \pm 0.01$ & $\begin{array}{l}0.14 \pm 0.03 \mathrm{~ns} \\
0.15 \pm 0.02 \mathrm{~ns} \\
0.15 \pm 0.01 \mathrm{~ns}\end{array}$ & $\begin{array}{l}0.16 \pm 0.01 \mathrm{~ns} \\
0.18 \pm 0.03 \mathrm{~ns} \\
0.15 \pm 0.00 \mathrm{~ns}\end{array}$ & $\begin{array}{l}\text { TSS } \\
0.19 \pm 0.01 \mathrm{a} \\
0.16 \pm 0.00 \mathrm{~b} \\
0.16 \pm 0.00 \mathrm{~b}\end{array}$ & $\begin{array}{c}\text { x titratable acidity } \\
0.17 \pm 0.02 \mathrm{~ns} \\
0.18 \pm 0.01 \mathrm{~ns} \\
0.16 \pm 0.01 \mathrm{~ns}\end{array}$ & $\begin{array}{l}0.17 \pm 0.00 \mathrm{~ns} \\
0.18 \pm 0.00 \mathrm{~ns} \\
0.17 \pm 0.01 \mathrm{~ns}\end{array}$ & $\begin{array}{l}0.18 \pm 0.00 \mathrm{~b} \\
0.19 \pm 0.00 \mathrm{a} \\
0.18 \pm 0.00 \mathrm{~b}\end{array}$ & $\begin{array}{l}0.19 \pm 0.01 \mathrm{~ns} \\
0.19 \pm 0.01 \mathrm{~ns} \\
0.18 \pm 0.00 \mathrm{~ns}\end{array}$ \\
\hline $\begin{array}{l}\text { Control } \\
\text { C1 } 2^{\circ} \\
\text { C2 } 2\end{array}$ & $58.03 \pm 0.62$ & $\begin{array}{l}53.30 \pm 0.67 \mathrm{~ns} \\
52.61 \pm 3.34 \mathrm{~ns} \\
51.20 \pm 1.28 \mathrm{~ns}\end{array}$ & $\begin{array}{l}50.19 \pm 1.81 \mathrm{~ns} \\
49.03 \pm 3.99 \mathrm{~ns} \\
51.95 \pm 2.68 \mathrm{~ns}\end{array}$ & $\begin{array}{l}50.76 \pm 2.18 \mathrm{~ns} \\
49.83 \pm 1.76 \mathrm{~ns} \\
51.62 \pm 2.20 \mathrm{~ns}\end{array}$ & $\begin{array}{r}\text { Colour (L) } \\
49.94 \pm 2.30 \mathrm{~ns} \\
48.81 \pm 1.72 \mathrm{~ns} \\
48.29 \pm 3.24 \mathrm{~ns}\end{array}$ & $\begin{array}{l}50.80 \pm 2.57 \mathrm{~ns} \\
48.69 \pm 2.70 \mathrm{~ns} \\
49.63 \pm 3.13 \mathrm{~ns}\end{array}$ & $\begin{array}{l}50.93 \pm 2.05 \mathrm{~ns} \\
50.42 \pm 1.78 \mathrm{~ns} \\
49.15 \pm 2.28 \mathrm{~ns}\end{array}$ & $\begin{array}{l}50.39 \pm 1.48 \mathrm{~ns} \\
49.29 \pm 2.56 \mathrm{~ns} \\
49.15 \pm 3.74 \mathrm{~ns}\end{array}$ \\
\hline
\end{tabular}


Table 3. TPA parameters of baby kiwi samples at $24 \pm 1^{\circ} \mathrm{C}$.

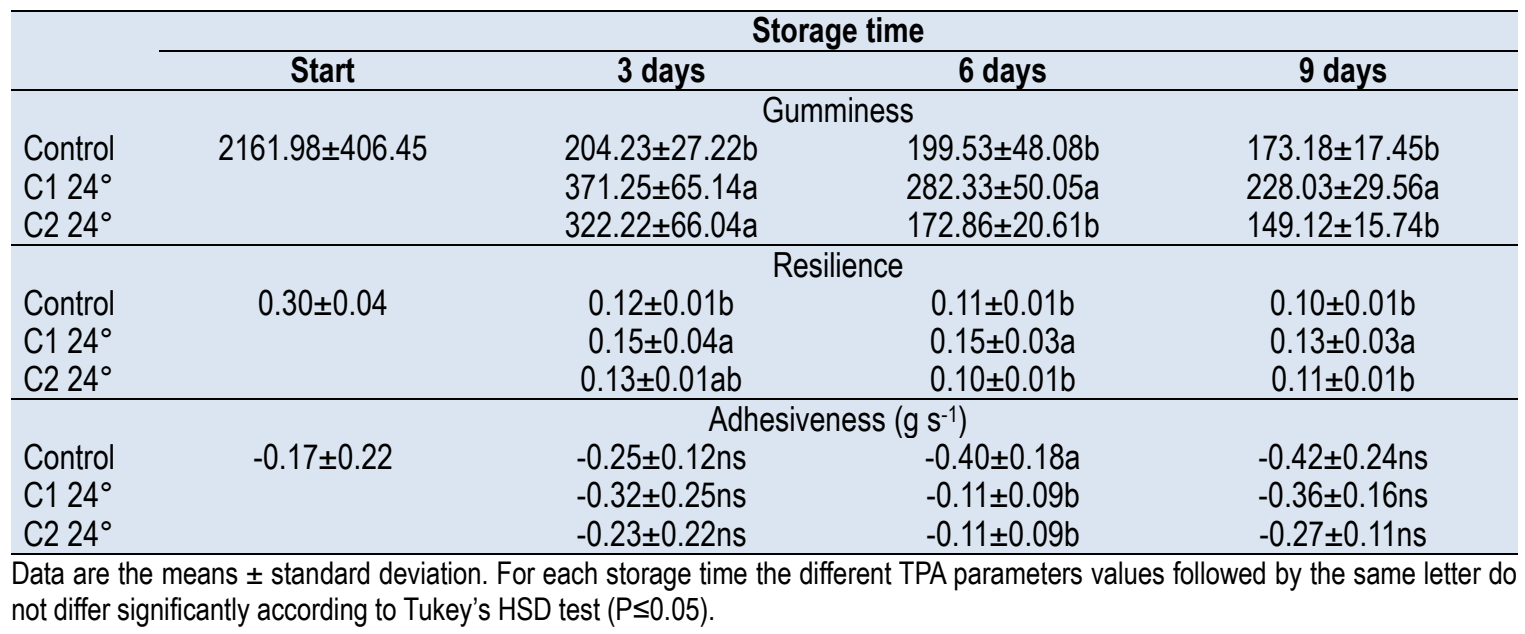

Table 4. TPA parameters of baby kiwi samples at $2 \pm 1^{\circ} \mathrm{C}$.

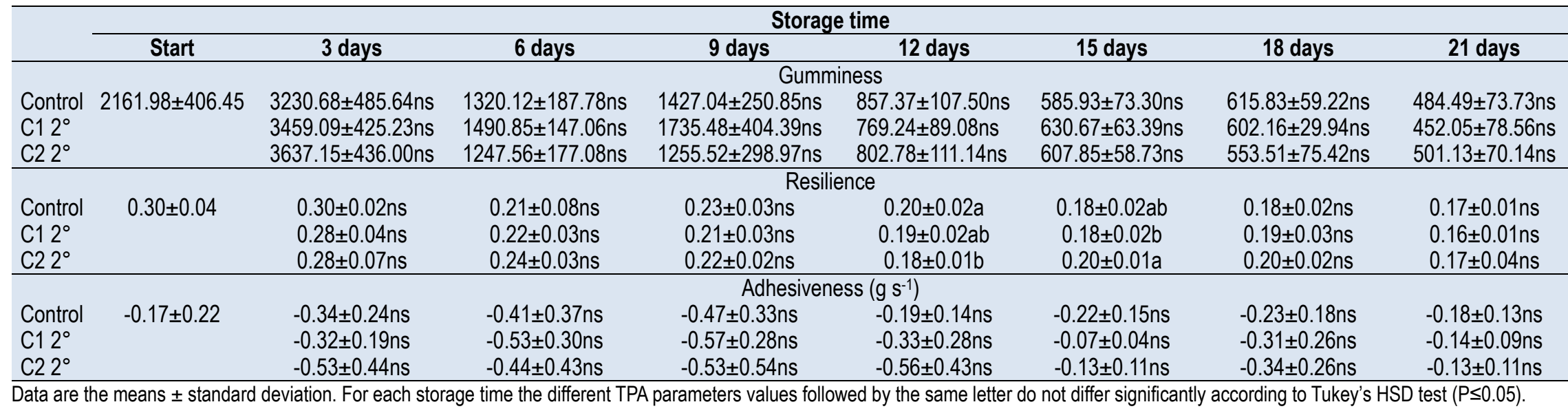




\section{CONCLUSIONS}

In agreement with the literature (Fisk et al., 2008), the tested coatings did not show a significant ability to limit weight losses at either storage temperature. In some cases, they showed a negative effect if compared with untreated fruits, as observed for the C2 coating, which was associated with an increase in TSS content. Even if this aspect has not been investigated, it is possible to suppose that the tested coatings probably did not substantially improve the barrier properties of baby kiwi peel (cuticle, epidermal cells and lenticels). These biological structures support fruit hydration, limiting the water diffusion process. The skin of baby kiwi is a very thin waxy layer, and this can affect the interaction with external and internal factors. Considering the $\mathrm{C} 2$ coating, its weaker effect may have been associated with its natural polysaccharide composition of a hydrophilic nature, which may have interacted more with the cuticular layer of the fruit, if compared with the mainly inert $\mathrm{C} 1$ coating. The C1 showed positive effects only at the highest storage temperature, conforming to the commercial formulation, which indicates the best effect in the temperature range of 20 to $25^{\circ} \mathrm{C}$; therefore, it can be hypothesized that low temperatures can reduce the effectiveness of this treatment, as observed here. In conclusion, the selection of new coating formulations and methodologies to dip or spray perishable fruits such as baby kiwi are required in order for this technique to be applied successfully in the postharvest supply chain of the fresh fruit market.

\section{Literature cited}

Fisk, C., McDaniel, M., Strik, B., and Zhao, Y. (2006). Physocochemical, sensory and nutritive qualities of hardy kiwifruit (Actinidia arguta 'Ananasnaya') as affected by harvest maturity and storage. J. Food Sci. 71 (3), S204-S210 https://doi.org/10.1111/j.1365-2621.2006.tb15642.x.

Fisk, C., Silver, A., Strik, B., and Zhao, Y. (2008). Postharvest quality of hardy kiwifruit (Actinidia arguta 'Ananasnaya') associated with packaging and storage conditions. Postharvest Biol. Technol. 47 (3), 338-345 https://doi.org/ 10.1016/j.postharvbio.2007.07.015.

Giuggioli, N.R., Girgenti, V., Baudino, C., Giacalone, G., and Chiabrando, V. (2017). Predictions models for the softening on new commercial Actinidia cultivars. J. Food Process. Preserv. 41 (6), e13245 https://doi.org/10. 1111/jfpp.13245.

Giuggioli, N., Briano, R., Baudino, C., and Peano, C. (2019). Post-harvest warehouse management of Actinidia arguta fruits. Pol. J. Food Nutr. Sci. 69 (1), 63-70 https://doi.org/10.31883/pjfns-2019-0006.

Kaya, M., Česonienè, L., Daubaras, R., Leskauskaitè, D., and Zabulionè, D. (2016). Chitosan coating of red kiwifruit (Actinidia melanandra) for extending of the shelf life. Int J Biol Macromol 85, 355-360 https://doi.org/10.1016/j. ijbiomac.2016.01.012. PubMed

Latocha, P., Krupa, T., Jankowski, P., and Radzanowska, J. (2014). Changes in postharvest physicochemical and sensory characteristics of hardy kiwifruit (Actinidia arguta and its hybrid) after cold storage under normal versus controlled atmosphere. Postharvest Biol. Technol. 88, 21-33 https://doi.org/10.1016/j.postharvbio.2013.09.005.

Latocha, P., Vereecke, D., and Debersaques, F. (2018). Kiwiberry commercial production - what stage are we at? Acta Hortic. 1218, 559-564 https://doi.org/10.17660/ActaHortic.2018.1218.76.

Liu, C., Jin, T., Liu, W., Hao, W., Yan, L., and Zheng, L. (2021). Effects of hydroxyethyl cellulose and sodium alginate edible coating containing asparagus waste extract on postharvest quality of strawberry fruit. LWT 148,111770 https://doi.org/10.1016/j.lwt.2021.111770.

Manzoor, S., Gull, A., Wani, S.M., Ganaie, T.A., Masoodi, F.A., Bashir, K., Malik, A.R., and Dar, B.N. (2021). Improving the shelf life of fresh cut kiwi using nanoemulsion coatings with antioxidant and antimicrobial agents. Food Biosci. 41, 101015 https://doi.org/10.1016/j.fbio.2021.101015.

Maringgal, B., Hashim, N., Tawakkal, I., and Mohamed, M. (2020). Recent advance in edible coating and its effect on fresh/fresh-cut fruits quality. Trends Food Sci. Technol. 96, 253-267 https://doi.org/10.1016/j.tifs.2019.12.024.

McNeilage, M.A., Beatson, R.A., and Macrae, E.A. (2004). Patent N US PP14,625 P3 United States Plant Patent, p.1-6.

Md Nor, S., and Ding, P. (2020). Trends and advances in edible biopolymer coating for tropical fruit: a review. Food Res Int 134, 109208 https://doi.org/10.1016/j.foodres.2020.109208. PubMed

Nardozza, S., Boldingh, H.L., Osorio, S., Höhne, M., Wohlers, M., Gleave, A.P., MacRae, E.A., Richardson, A.C., Atkinson, R.G., Sulpice, R., et al. (2013). Metabolic analysis of kiwifruit (Actinidia deliciosa) berries from extreme genotypes reveals hallmarks for fruit starch metabolism. J Exp Bot 64 (16), 5049-5063 https://doi.org/10.1093/jxb/ert293. 
PubMed

Pathare, P.B., Opara, U.L., and Al-Said, F.A.J. (2013). Colour measurement and analysis in fresh and processed foods: a review. Food Bioprocess Technol. 6 (1), 36-60 https://doi.org/10.1007/s11947-012-0867-9.

Pobiega, K., Igielska, M., Włodarczyk, P., and Gniewosz, M. (2021). The use of pullulan coatings with propolis extract to extend the shelf life of blueberry (Vaccinium corymbosum) fruit. Int. J. Food Sci. Technol. 56 (2), 1013-1020 https://doi.org/10.1111/ijfs.14753.

Sutherland, P., Fullerton, C., Schroder, R., and Hallett, I. (2017). Cell wall changes in Actinidia arguta during softening. Sci. Hortic. (Amsterdam) 226, 173-183 https://doi.org/10.1016/j.scienta.2017.08.027.

Szpadzik, E., Zaraś-Januszkiewicz, E., and Krupa, T. (2021). Storage quality characteristic of two minikiwi fruit (Actinidia arguta (Siebold \& Zucc.) Planch. ex Miq.) cultivars: 'Ananasnaya' and 'Bingo' - a new one selected in Poland. Agronomy (Basel) 11 (1), 134 https://doi.org/10.3390/agronomy11010134.

Yang, E., Zhao, Y., and Qian, M.C. (2010). Effect of edible coating on volatile compounds of hardy kiwifruit during storage. ACS Symposium Series 1035, 79-94 https://doi.org/10.1021/bk-2010-1035.ch006. 
